\title{
REEXAMINATION OF THE MIDDLE DEVONIAN PLUM BROOK SHALE OF ERIE COUNTY, OHIO, U.S.A.
}

SIBILA*, Daniel W., Dept. of Geology, University of Toledo, Toledo, OH 43606, U.S.A.; KAMPOURIS, George E., 2354 Kenwood Blvd. , Toledo, OH 43606, U.S.A.; CAMP, Mark J., Dept. of Geology, University of Toledo, Toledo, $\mathrm{OH} 43606$, U.S.A.

Newberry (1874) was the first to describe the alternating shale and carbonate sequence near Sandusky, Ohio. He proposed the name of Olentangy Shale based upon the similarities of the beds to the outcrops along the Olentangy River in central Ohio, later supported by the work of Orton (1893) and Stauffer $(1909,1916)$. Grabau (1917) disagreed with the Olentangy correlation and suggested Plum Creek Shale for the section, which later was changed to Plum Brook (Cooper 1930), because it is the official designation of the stream at the type locality.

Stumm (1942) conducted the last major study of the Plum Brook Shale dividing the section into seven units at the type locality. He mentioned each of the shale zones as being completely covered and described collecting fossils loosely on the bank or by digging into the slope. Legitimacy of characteristic fauna in the shale zones is questioned since it is possible that fossils embedded on the soft shale may have originated from weathering of the limestone bands.

With the onset of World War II, additional studies of the type locality became restricted when the area was turned into a government TNT manufacturing facility. Recently, the current operating facility, NASA Plum Brook Station, permitted the excavation of several 2 meter pits with a back hoe along Plum Brook. Therefore, for the first time, in situ analysis of the shale units and limestone bands was possible.

Stumm's former work provided a stratigraphic framework to distinguish the units, but boundary changes were necessary in order to create a distinct lithofacies split between the transitions of shale and carbonate resulting from eustatic changes during Hamilton deposition. The boundary changes were based upon a dominant presence of carbonate in the transition zones, as well as the representation of similar fauna between the transition zones and the hard carbonate bands.

Unit A, a 4.5 meter thick mainly unfossiliferous gray calcareous shale, is characterized by interbedding of four unfossiliferous concretion horizons in the upper 3 meters of the unit. The lower 1.5 meter section contains two thin horizons of pyritized fauna of Bactrites arkonensis and Tornoceras uniangulare. Unit B begins above the last concretion horizon of Unit A, and is characterized by a 60 cm brown fossiliferous hash containing "Anomalotoechus sp.", Devonochonetes spp., and Leiorhynchus kelloggi. A $10 \mathrm{~cm}$ crystalline limestone rests upon the hash and is characterized by Phacops rana and orthoconic nautiloids. The 1.8 meter thick Unit $C$ is a soft gray, relatively unfossiliferous calcareous shale, except near the contact with Unit B where strata yield Devonochonetes spp., Leiorhynchus kelloggi, and Protitanichthys sp. Unit D is similar to Unit B because of the fossil hash transition zone, but it does not contain "Anomalotoechus sp." The hard limestone is two distinct bedding planes of 10 to $15 \mathrm{~cm}$, characterized by Mucrospirifer mucronatus, Megastrophia concava, and Phacops rana. Unit $\mathrm{E}$ is a $90 \mathrm{~cm}$ gray calcareous shale containing sparse Devonochonetes spp. Unit F marks the last limestone band consisting of three distinct layers. A detrital hash marks the lower 5 to $10 \mathrm{~cm}$. This is overlain by 10 to $15 \mathrm{~cm}$ fossil hash similar to Unit $D$. A $10 \mathrm{~cm}$ friable limestone containing Leiorhynchus kelloggi, Paracyclas lirata, Platyceras arkonense, and Phacops rana forms the uppermost layer of Unit F. Unit G, a $90 \mathrm{~cm}$ gray unfossiliferous calcareous shale unit containing pyrite nodules, completes the Plum Brook Shale deposition.

Reexamination of the Middle Devonian Plum Brook Shale along Plum Brook delineated lithofacies and characteristic fauna of the units described by Stumm. This strengthens the correlation of Plum Brook Shale with similar strata located in northwestern Ohio, eastern Michigan, southern Ontario, and western New York. 